\title{
Coexistence of Porphyromonas gingivalis, Tannerella forsythia and Treponema denticola in the Red Bacterial Complex in Chronic Periodontitis Subjects
}

\author{
Coexistencia de Porphyromonas gingivalis, Tannerella forsythia y Treponema denticola \\ en el Complejo Rojo Bacteriano en Sujetos con Periodontitis Crónica
}

\author{
Carlos Martín Ardila Medina; Astrid Adriana Ariza Garcés \& Isabel Cristina Guzmán Zuluaga
}

ARDILA, M. C. M.; ARIZA, G. A. A. \& GUZMÁN, Z. I. C. Coexistence of Porphyromonas gingivalis, Tannerella forsythia and Treponema denticola in the red bacterial complex in chronic periodontitis. Int. J. Odontostomat., 8(3):359-364, 2014.

ABSTRACT: Previous reports showed that periodontitis is associated with different microorganisms rather than individual periodontopathogens in the dental biofilm. The purpose of the current study was to evaluate the coexistence and relationship among Porphyromonas gingivalis, Tanerella forsythia, and Treponema denticola in the red complex, noting its association with the severity of periodontitis. In this cross sectional study, 96 subjects, aged 33 to 82 years (with $\geq 18$ residual teeth) with chronic periodontitis who attended the dental clinics of the Universidad de Antioquia in Medellín, Colombia were invited to participate. The presence or absence of bleeding on probing and plaque were registered. Probing depth and clinical attachment level were measured at all approximal, buccal and lingual surfaces. Microbial sampling on periodontitis patients was performed on pockets $>5 \mathrm{~mm}$. The presence of $P$. gingivalis, $T$. forsythia, and $T$. denticola was detected by PCR using primers designed to target the respective $16 \mathrm{~S}$ rRNA gene sequences. The coexistence of the three periodontopathogens was the most frequent (25 subjects). A statistically significant association between the three bacteria was observed $(P$. gingivalis and T. forsythia, $\mathrm{P}<0.0001 ; P$. gingivalis and T. denticola, $\mathrm{P}=0.001 ; T$. forsythia and $T$. denticola, $\mathrm{P}<0.0001$ ). Similarly, the logistic regression analysis showed a significant association among periodontopathogens. The most relevant was observed between $P$. gingivalis and $T$. forsythia $(\mathrm{OR}=6.1)$. In conclusion, the present study found a significant association in the coexistence of $P$. gingivalis, $T$. forsythia and $T$. denticola, and they related strongly to clinical parameters of inflammation and periodontal destruction.

KEY WORDS: periodontitis, tannerella forsythia, porphyromonas gingivalis, treponema denticola, coaggregation.

\section{INTRODUCTION}

Periodontitis is an oral inflammatory disease provoked principally by gram-negative microorganisms that will induce a local and systemic inflammatory response, leading to periodontal tissue damage. Previous report showed that periodontitis is associated with different microorganisms rather than individual periodontopathogens in the dental biofilm, defining five microbial complexes. The red complex, considered the most pathogenic, appears later in the biofilm including three pathogens: Porphyromonas gingivalis, Tannerella forsythia and
Treponema denticola (Socranski et al., 1998). Red complex bacteria have been shown to employ neuraminidases to scavenge host sialic acid for use as an embellishing molecule. This method supports the periodontal pathogens to avoid host immune defenses (Amano et al., 2014). P. gingivalis can locally invade periodontal tissues and evade the host defense mechanisms and utilizes a panel of virulence factors that cause deregulation of the innate immune and inflammatory responses. The ability of $P$. gingivalis to cause chronic periodontitis is resolute

\footnotetext{
* Epidemiology, Chief of Stomatology Group Research, School of Dentistry, Universidad de Antioquia, Medellín, Colombia.

* Ph. D in Epidemiology, Dentist, Universidad de Antioquia, Medellín, Colombia.

${ }^{* * *}$ Periodontist, Universidad de Antioquia, Medellín, Colombia.
} 
by its store of virulence factors. Biofilm development and bacterial dipeptidyl peptidase IV activity provide to its pathogenic potential (Clais et al., 2014). T. forsythia virulence factors are beginning to be adequately identified and characterized, including the surface antigen BspA, a hemagglutinin, cell envelope lipoproteins, cell surface proteolytic enzymes, glycosidases, and the cell surface layer. Besides that, lipopolysaccharide (LPS), which is present in the outer membrane of most Gram-negative bacteria for both its structural and functional integrity, is a well-known immunostimulatory agent serving as one of the primary targets of the innate arm of the mammalian immune system (Posch et al., 2013). T. denticola outer membrane revealed the presence of a lipooligosaccharide, similar in overall structure and function to the LPS; it has a distinctly different pattern of sugar molecules and lacks the lipid A component of a typical LPS, becoming a primary activator of inflammatory responses.

The distribution and occurrence of periodontal pathogens change depending on geographic situations highlighting the importance of studying different locations (Haffajee et al., 2004). However correlation between coinfection of these three microbes with severity of periodontitis is not adequately documented in Latin America. Various studies have shown the prevalence of periodontal pathogens (Haffajee et al.; Ardila et al., 2012; Lafaurie et al., 2007) but they do not explicit their relationship properly and some of them have used only cultivation techniques that are not appropriate to identify them, this is the case of $T$. forsythia, periodontal pathogen that has remained an under investigation because of its fastidious growth and recalcitrant nature to genetic manipulation (Amano et al.); on the other hand, $T$. denticola is the difficulty in cultivating them, moreover, progress in molecular analysis of specific T. denticola behaviors has been considerably slowed by the limitations of currently available genetic systems for this organism (Fenno, 2012) Moreover, a better understanding of the composition of the subgingival plaque and the association of periodontal pathogens with periodontal status in a particular population are crucial to carry out the most effective periodontal treatment.

Thus, the objective of this investigation was to evaluate the coexistence and relationship among $P$. gingivalis, T. forsythia, and T. denticola in the red complex, noting its association with the severity of periodontitis.

\section{MATERIAL AND METHOD}

In this cross sectional study, 96 subjects, aged 33 to 82 years (with $\geq 18$ residual teeth) with chronic periodontitis who attended the dental clinics of the Universidad de Antioquia in Medellín, Colombia were invited to participate between January 2009 and December 2011. Informed and written consent was obtained from each participant. The study design was approved by the Ethics Committee on Human Research of the School of Dentistry of the University of Antioquia according to the Declaration of Helsinki on experimentation involving human subjects.

Exclusion criteria included diagnosed diabetes and autoimmune diseases. Pregnant women, previous (six months) consumption of systemic antimicrobials, non-steroidal analgesics or antiinflammatory drugs, and previous periodontal therapy also served as exclusion criteria.

Medical history and clinical and radiographic examination were conducted for each patient. The diagnosis of chronic periodontitis was made based on criteria defined by Eke et al. (2012); subjects were classified as moderate periodontitis by $\geq 2$ interproximal sides with clinical attachment level $(C A L) \geq 4 \mathrm{~mm}$, or by $\geq 2$ interproximal sides with probing depth (PD) $\geq 5 \mathrm{~mm}$ (not at the same tooth). Severe periodontitis was characterized by $\geq 2$ interproximal sides with CAL $\geq 6 \mathrm{~mm}$ and $\geq 1$ interproximal side with $P D \geq 5 \mathrm{~mm}$ (not at the same tooth). Subjects with no evidence of mild, moderate, or severe periodontitis were used as control group.

A trained and calibrated clinician performed all clinical examinations. The intra-examiner reproducibility was assessed before and during the study. The intra-class correlation coefficients for mean PD and CAL were 0.92 and 0.91 , respectively; the intra-evaluator kappa index were in the range 0.850.96 The presence or absence of bleeding on probing $(B O P)$ and plaque were registered. PD and CAL were measured at all proximal, buccal and lingual surfaces to the nearest millimeter by a calibrated standard probe (UNC-15, Hu-Friedy, Chicago, IL).

Microbial Sampling. Microbial sampling on periodontitis patients was performed on pockets $>5$ $\mathrm{mm}$. The deepest six pockets were selected for sampling. After removing supragingival plaque with curette and isolating the area with cotton pellets, the 
paper points (Maillefer, Ballaigues, Switzerland) were inserted into each periodontal pocket for 20 seconds. One paper point from each site was introduced into an empty $1.5 \mathrm{ml}$ micro-fuge tube for polymerase chain reaction (PCR) analysis.

The presence of $P$. gingivalis, T. forsythia, and T. denticola was detected by PCR using primers designed to target the respective 16S rRNA gene sequences, according to the method of Ashimoto et al. (1996). Briefly, PCR mixtures (50 mL) were prepared with $5 \mathrm{~mL}$ of bacterial DNA (GoTaq Flexi DNA Polymerase, Promega), $0.5 \mathrm{mM}$ species-specific primers, $10 \mathrm{~mL}$ of 5 PCR buffer (Deoxynucleotide Triphosphates, Promega),1.25 $U$ of Taq DNA polymerase, \# $0.2 \mathrm{mM}$ dNTP mix, and $1.5 \mathrm{mM} \mathrm{MgCl} 2$. Gene-specific amplification was performed in a thermal cycler (MyCycler® Termal Cycler), Bio-Rad with the following thermal profiles: T. forsythia and T. denticola, initial denaturation step at $95^{\circ} \mathrm{C}$ for 2 minutes, followed by 36 cycles of denaturation at $95^{\circ} \mathrm{C}$ for 30 seconds, annealing at $60^{\circ} \mathrm{C}$ for 1 minute and extension at $72^{\circ} \mathrm{C}$ for 1 minute, and a final extension at $72^{\circ} \mathrm{C}$ for 2 minutes. PCR products were electrophoresed on $1 \%$ agarose gels and stained with $0.5 \mathrm{mg} / \mathrm{mL}$ ethidium bromide, and the presence of target bands for each bacterium was confirmed.

Statistical Analysis. Differences in continuous and categorical variables were examined with independent t test (data were distributed normally) and X2 test, respectively. Associations between periodontal pathogens were assessed by logistic regression analysis. The OR and corresponding 95\% confidence intervals were calculated for each microorganism. $P$ values of $<0.05$ were considered statistically significant. All analyses were performed using statistical software (SPSS version 15.0; SPSS, Chicago, IL).

\section{RESULTS}

A total of 72 women and 24 men with chronic periodontitis were studied. Table I depicts the demographic characteristics and periodontal parameters of the subjects. A higher number of women and non-smokers were observed. When comparing smokers and non-smokers higher PD and CAL lost were observed.

Table II shows coexistence of microorganisms in the red complex and their frequency in patients with chronic periodontitis. The coexistence of the three periodontopathogens was the most frequent (25 subjects). A statistically significant association between the three bacteria was observed ( $P$. gingivalis and T. forsythia, $P<0.0001 ; P$. gingivalis and T. denticola, $\mathrm{P}=0.001 ; \mathrm{T}$. forsythia and T. denticola, $\mathrm{P}<0.0001)$. Interestingly, in 22 subjects the presence of any bacteria was identified. In summary, in coexistence of the three bacteria, higher PD and CAL lost were noticed (Table III).

On the other hand, in bivariate analysis a strong association between smoking and $T$. forsythia was observed $(P<0.0001)$. Consistent with this result, the logistic regression analysis (crude model) confirmed this association $(\mathrm{OR}=2.72,95 \%$ confidence interval $[\mathrm{Cl}]=1.09-6.8 ; \mathrm{P}=0.031$ ). This statistically significant association remained after adjustment for age and $\operatorname{sex}(\mathrm{OR}=2.75,95 \% \mathrm{Cl}=1.09-6.9 ; \mathrm{P}=0.032)$.

Similarly, the logistic regression analysis showed a significant association among periodontopathogens (Table IV). The most relevant was observed between $P$. gingivalis and $T$. forsythia (OR=6.1).

Table I. Demographic characteristics and periodontal parameters of the patients with periodontitis.

\begin{tabular}{llc}
\hline Parameter & & $\begin{array}{c}\text { Periodontitis subjects } \\
(\mathbf{n = 9 6 )}\end{array}$ \\
\hline Age (years \pm SD) & Female & $46 \pm 9.3$ \\
Sex & Male & $75 \%$ \\
Smoking & Non-smokers & $25 \%$ \\
& Smokers & $72 \%$ \\
PD $(m m \pm S D)$ & & $28 \%$ \\
CAL $(m m \pm S D)$ & & $3.6 \pm 1.1$ \\
Plaque & & $4.3 \pm 1.4$ \\
BOP & & $54 \%$ \\
\hline
\end{tabular}

$\mathrm{SD}=$ Standard Deviation. 
Table II. Coexistence of microorganisms in the red complex and their frequency in patients with chronic periodontitis.

\begin{tabular}{lcc}
\hline Periodontopathogens & Frequency & $\%$ \\
\hline P. gingivalis, T. forsythia and T. denticola & 25 & 26 \\
P. gingivalis and T. forsythia & 19 & 19.8 \\
P. gingivalis and T. denticola & 4 & 4.2 \\
T. forsythia and T. denticola & 4 & 4.2 \\
P. gingivalis & 12 & 12.5 \\
T. forsythia & 8 & 8.3 \\
T. denticola & 2 & 2.1 \\
None & 22 & 22.9 \\
\hline
\end{tabular}

Table III. Coexistence of red complex microorganisms and periodontal parameters.

\begin{tabular}{|c|c|c|c|c|}
\hline Microorganisms & $\begin{array}{c}\text { PD } \\
(m m \pm S D)\end{array}$ & 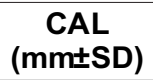 & $\begin{array}{l}\text { Plaque } \\
\text { (\%土SD) }\end{array}$ & 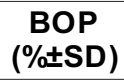 \\
\hline P. gingivalis, T. forsythia and T. denticola & $3.8 \pm 0.8$ & $4.7 \pm 1.1$ & $46 \pm 28$ & $50 \pm 27$ \\
\hline$P$. gingivalis and $T$. forsythia & $3.7 \pm 1.5$ & $4.5 \pm 1.7$ & $51 \pm 32$ & $49 \pm 31$ \\
\hline$P$. gingivalis and $T$. denticola & $3.3 \pm 1.5$ & $3.9 \pm 1.2$ & $35 \pm 18$ & $30 \pm 15$ \\
\hline T. forsythia and T. denticola & $3.5 \pm 1.1$ & $4.6 \pm 1.4$ & $66 \pm 34$ & $40 \pm 20$ \\
\hline$P$. gingivalis & $3.7 \pm 1.1$ & $4.5 \pm 1.5$ & $55 \pm 38$ & $47 \pm 37$ \\
\hline T. forsythia & $3.2 \pm 1.2$ & $3.5 \pm 1.1$ & $49 \pm 32$ & $39 \pm 30$ \\
\hline T. denticola & $2.3 \pm 1.1$ & $2.1 \pm 1.2$ & $63 \pm 51$ & $70 \pm 27$ \\
\hline
\end{tabular}

$\mathrm{SD}=$ Standard Deviation .

Table IV. Associations among periodontal pathogens evaluated.

\begin{tabular}{lcccccc}
\hline & \multicolumn{3}{c}{ T. forsythia } & \multicolumn{3}{c}{ T. denticola } \\
& OR & $\mathbf{9 5 \%}$ IC & $\boldsymbol{P}$ value & OR & $\mathbf{9 5 \%}$ IC & $\boldsymbol{P}$ value \\
\hline P. gingivalis & 6.1 & $2.6-14.2$ & $<0.0001$ & 4.7 & $1.8-12$ & 0.001 \\
$T$. forsythia & --- & --- & --- & 5 & $1.9-12.3$ & 0.001 \\
\hline
\end{tabular}

\section{DISCUSSION}

The outcomes of this investigation specify that the associations among coexistence of $P$. gingivalis, $T$. forsythia and $T$. denticola, namely the red complex and $C A L, P D$ and BOP were significant in chronic periodontitis, suggesting an important role in the progression of chronic periodontitis. Confirming our results, previous investigations showed similar relationships (Haffajee et al.; Ardila et al.; Lafaurie et al.); however they did not report the coexistence and its relation to periodontal parameters in detail as was done in this study. Thus, in sites with higher PD and CAL lost a higher frequency of the coexistence $P$. gingivalis, $T$. forsythia and $T$. denticola was shown, ratifying the solid association between chronic periodontitis and red complex species, previously presented (Haffajee et al.; Socransky et al.).

Coaggregation between microorganisms plays a key role in the colonization of the gingival crevice and the organization of periodontopathic biofilms. In this study, the logistic regression analysis showed a significant association among $P$. gingivalis, $T$. forsythia and $T$. denticola. It has been shown that members of this red complex coaggregate strongly in vitro (Yao et al., 1996) and one species of the complex may produce growth factors required by another in that complex (Nilius et al., 1993). Analogously, Hashimoto et al. (2003) suggested that $P$. gingivalis fimbriae and $T$. denticola dentilisin are implicated in the coaggregation of these bacteria; Meuric et al. (2013) showed that interactions of $P$. gingivalis with other bacterial species, such as $T$. denticola, induce increased adhesive capacities on various substrata by hemagglutinin adhesion domain-containing proteins. Besides, the surface layer of $T$. forsythia is composed of cell surface glycoproteins, such as TfsA and TfsB, and is known to 
play a role in adhesion/invasion and suppression of proinflammatory cytokine expression (Shimotahira et al., 2013).

The current study has a particular interest because a strong association between smoking and $T$. forsythia was observed $(P<0.0001)$ which remained after adjustment for age and sex $(\mathrm{OR}=2.75,95 \% \mathrm{Cl}=$ 1.09-6.9; $P=0.032)$. Similar results presented Guglielmetti et al. (2014), showing that counts of $T$. forsythia were higher in smokers. The correlation observed could be the result of the lower pocket oxygen tension found in smokers with periodontitis, compared to non-smokers (Hanioka et al., 2000). Another mechanism of action involved could be the smokingpromoted selective adherence of periodontal pathogens to the epithelial surfaces of periodontal pockets (Guglielmetti et al.).
In conclusion, the present study found a significant association in the coexistence of $P$. gingivalis, T. forsythia and T. denticola, and they related strongly to clinical parameters of inflammation and periodontal destruction. Further studies are needed to find out the molecular mechanisms underlying the coaggregation between periodontal pathogens.

\section{ACKNOWLEDGEMENTS}

This study was supported by a grant from the Colombian Institute of Science and Technology "Francisco José de Caldas" COLCIENCIAS (No 1308-0411854).

The authors report no conflicts of interest related to this study.

ARDILA, M. C. M.; ARIZA, G. A. A. \& GUZMÁN, Z. I. C. Coexistencia de Porphyromonas gingivalis, Tannerella forsythia y Treponema denticola en el complejo rojo bacteriano en sujetos con periodontitis crónica. Int. J. Odontostomat., 8(3):359$364,2014$.

RESUMEN: Reportes previos mostraron que la periodontitis se asocia con diferentes microorganismos en lugar de periodontopatógenos particulares en la biopelícula dental. El objetivo del presente estudio fue evaluar la coexistencia y relación entre Porphyromonas gingivalis, Tanerella forsythia y Treponema denticola en el complejo rojo, señalando su vinculación con la severidad de la periodontitis. En este estudio transversal, 96 sujetos de 33 a 82 años (con $\geq 18$ dientes residuales) con periodontitis crónica que asistieron a las clínicas dentales de la Universidad de Antioquia en Medellín, Colombia fueron invitados a participar. Se registraron la presencia o ausencia de sangrado al sondaje y placa. La profundidad de sondaje y nivel de inserción clínica se midieron en todas las superficies proximales, bucal y lingual. El muestreo microbiano en pacientes con periodontitis se realizó en los bolsillos mayores a $5 \mathrm{~mm}$. La presencia de $P$. gingivalis, $T$. forsythia, y T. denticola se detectó por PCR usando las bolsas periodontales diseñadas para dirigirse a las respectivas secuencias de genes 16S RNAr. La coexistencia de los tres periodontopatógenos fue la más frecuente (25 sujetos). Se observó una asociación estadísticamente significativa entre las tres bacterias ( $P$. gingivalis y $T$. forsythia, $\mathrm{P}<0,0001 ; P$. gingivalis y $T$. denticola, $\mathrm{P}=0,001 ; T$. forsythia y $T$. denticola, $\mathrm{P}<0,0001)$. Del mismo modo, el análisis de regresión logística mostró una asociación significativa entre periodontopatógenos; la más relevantes se observó entre $P$. gingivalis y $T$. forsythia $(\mathrm{OR}=6,1)$. El presente estudio encontró una asociación significativa en la coexistencia de $P$. gingivalis, $T$. forsythia y $T$. denticola, y estuvieron fuertemente relacionadas a los parámetros clínicos de la inflamación y destrucción periodontal.

PALABRAS CLAVE: periodontitis, Tannerella forsythia, Porphyromonas gingivalis, Treponema denticola, coagregación.

\section{REFERENCES}

Amano, A.; Chen, C.; Honma, K.; Li, C.; Settem, R. P. \& Sharma, A. Genetic characteristics and pathogenic mechanisms of periodontal pathogens. Adv. Dent. Res., 26(1):15-22, 2014.

Ardila, M. C. M.; Arbeláez, M. M. I. \& Guzman, Z. I. C. Perfil microbiológico subgingival de pacientes con periodontitis crónica en una población de Colombia. Av. Periodoncia, 24(1):47-53, 2012.
Ashimoto, A.; Chen, C.; Bakker, I. \& Slots, J. Polymerase chain reaction detection of 8 putative periodontal pathogens in subgingival plaque of gingivitis and advanced periodontitis lesions. Oral Microbiol. Immunol., 11(4):266-73, 1996.

Clais, S.; Boulet, G.; Kerstens, M.; Horemans, T.; Teughels, W.; Quirynen, M.; Lanckacker, E.; De Meester, I.; Lambeir, A. M.; Delputte, P.; Maes, L. 
\& Cos, P. Importance of biofilm formation and dipeptidyl peptidase IV for the pathogenicity of clinical Porphyromonas gingivalis isolates. Pathog. Dis., 70(3):408-13, 2014.

Eke, P. I.; Page, R. C.; Wei, L.; Thornton-Evans, G. \& Genco, R. J. Update of the case definitions for population-based surveillance of periodontitis. J. Periodontol., 83(12):1449-54, 2012.

Fenno, J. C. Treponema denticola interactions with host proteins. J. Oral Microbiol., 4:1-13, 2012.

Guglielmetti, M. R.; Rosa, E. F.; Lourenção, D. S.; Inoue, G.; Gomes, E. F.; De Micheli, G.; Mendes, F. M.; Hirata, R. D.; Hirata, M. H. \& Pannuti, C. M. Detection and quantification of periodontal pathogens in smokers and never-smokers with chronic periodontitis by real-time polymerase chain reaction. J. Periodontol., 85(10):1450-7, 2014.

Haffajee, A. D.; Bogren, A.; Hasturk, H.; Feres, M.; Lopez, N. J. \& Socransky, S. S. Subgingival microbiota of chronic periodontitis subjects from different geographic locations. J. Clin. Periodontol., 31(11):996-1002, 2004.

Hanioka, T.; Tanaka, M.; Takaya, K.; Matsumori, Y. \& Shizukuishi, S. Pocket oxygen tension in smokers and non-smokers with periodontal disease. J. Periodontol., 71(4):550-4, 2000.

Hashimoto, M.; Ogawa, S.; Asai, Y.; Takai, Y. \& Ogawa, T. Binding of Porphyromonas gingivalis fimbriae to Treponema denticola dentilisin. F. E. M. S. Microbiol. Lett., 226(2):267-71, 2003.

Lafaurie, G. I.; Contreras, A.; Barón, A.; Botero, J.; Mayorga-Fayad, I.; Jaramillo, A.; Giraldo, A.; González, F.; Mantilla, S.; Botero, A.; Archila, L. H.; Díaz, A.; Chacón, T.; Castillo, D. M.; Betancourt, M.; Del Rosario Aya, M. \& Arce, R. Demographic, clinical, and microbial aspects of chronic and aggressive periodontitis in Colombia: a multicenter study. J. Periodontol., 78(4):629-39, 2007.

Meuric, V.; Martin, B.; Guyodo, H.; Rouillon, A.; Tamanai-Shacoori, Z.; Barloy-Hubler, F. \& Bonnaure-Mallet, M. Treponema denticola improves adhesive capacities of Porphyromonas gingivalis. Mol. Oral Microbiol., 28(1):40-53, 2013.

Nilius, A. M.; Spencer, S. C. \& Simonson, L. G.
Stimulation of in vitro growth of Treponema denticola by extracellular growth factors produced by Porphyromonas gingivalis. J. Dent. Res., 72(6):1027-31, 1993.

Posch, G.; Andrukhov, O.; Vinogradov, E.; Lindner, B.; Messner. P.; Holst, O. \& Schäffer, C. Structure and immunogenicity of the rough-type lipopolysaccharide from the periodontal pathogen Tannerella forsythia. Clin. Vaccine Immunol., 20(6):945-53, 2013.

Shimotahira, N.; Oogai, Y.; Kawada-Matsuo, M.; Yamada, S.; Fukutsuji, K.; Nagano, K., Yoshimura, F.; Noguchi, K. \& Komatsuzawa, H. The surface layer of Tannerella forsythia contributes to serum resistance and oral bacterial coaggregation. Infect. Immun., 81(4):1198-2206, 2013.

Socransky, S. S.; Haffajee, A. D.; Cugini, M. A.; Smith, C. \& Kent, R. L. Jr. Microbial complexes in subgingival plaque. J. Clin. Periodontol., 25(2):13444,1998.

Yao, E. S.; Lamont, R. J.; Leu, S. P. \& Weinberg, A. Interbacterial binding among strains of pathogenic and commensal oral bacterial species. Oral Microbiol. Immunol., 11(1):35-41,1996.

Correspondence to:

Carlos M. Ardila

Chief of Stomatology Group Research

School of Dentistry

Universidad de Antioquia

Calle 70 No. 52-21

Medellín

COLOMBIA

Email: martinardila@gmail.com

Recibido : 26-05-2014

Aceptado: 18-08-2014 